\title{
Earthbound Teaching Nature Connected Arts Therapy
}

\author{
Bettina Evans \\ Whitecliffe College of Arts and Design, New Zealand
}

\begin{abstract}
Nature connected arts therapy (NCAT) is still a relatively new field in education. This article is a first exploration of teaching nature connected arts therapy in a post graduate diploma course in New Zealand. Included are examples of the outdoor teaching sessions at Whitecliffe. This is paired with student voices and art work describing the student's experiences of interacting with nature and natural art materials during the sessions. The overarching theme of teaching NCAT in this setting is the widening of the concept of communitas to include nature. Furthermore NCAT provides the students with means of self-care which they can access during and outside of the programmeme.
\end{abstract}

Keywords: Nature connected arts therapy, Communitas with nature, Self-car, Naturalistic intelligence, Environmentally sensitive arts materials

Ko au tetaiao ko tetaiao ko au,

I am the environment, the environment is me.

(Māori whakatauki/proverb)

I am passionate about teaching nature connected arts therapy (NCAT) at Whitecliffe College in our post graduate diploma programme, yet I have struggled to write about it. Frustrated after a morning of writing many words but few that seem useful I go for a walk in the hills behind my house. After half an hour of following the contours of the Port Hills crater rim I sit on a rock to rest. Suddenly a pīwakawaka (or tīwakawaka, a fantail, a small indigenous, tree dwelling, insect catching bird) swoops close to me, twitters excitedly, dips up and down in a circle around me and then disappears back into the shrubs. I take this hint and decide to have two fantails, T⿳亠丷⿵ and P $\overline{1}$, lead my inquiry. I imagine they will flit in and out, helping me to find my way. Our students will be represented through their comments (in boxes) and the photos/artworks they kindly contributed. Special thanks go to Heleina for reminding me of the whakatauki here.

T1̄ settles on a ngaiobranch close to me and tilts his head: 'Why do you teach nature connected arts therapy?'As I look out over the rough, grassy shrub land a memory from my childhood arises:

I flop onto my stomach into the grassy meadow. The world as I know it disappears-a miniature forest of thickgrass stems surrounds me, interspersed by buttercups and other flowers I do not know the names of yet. Above the fingers of grass, the summer sky is blue. I'm six or seven years old, and I 


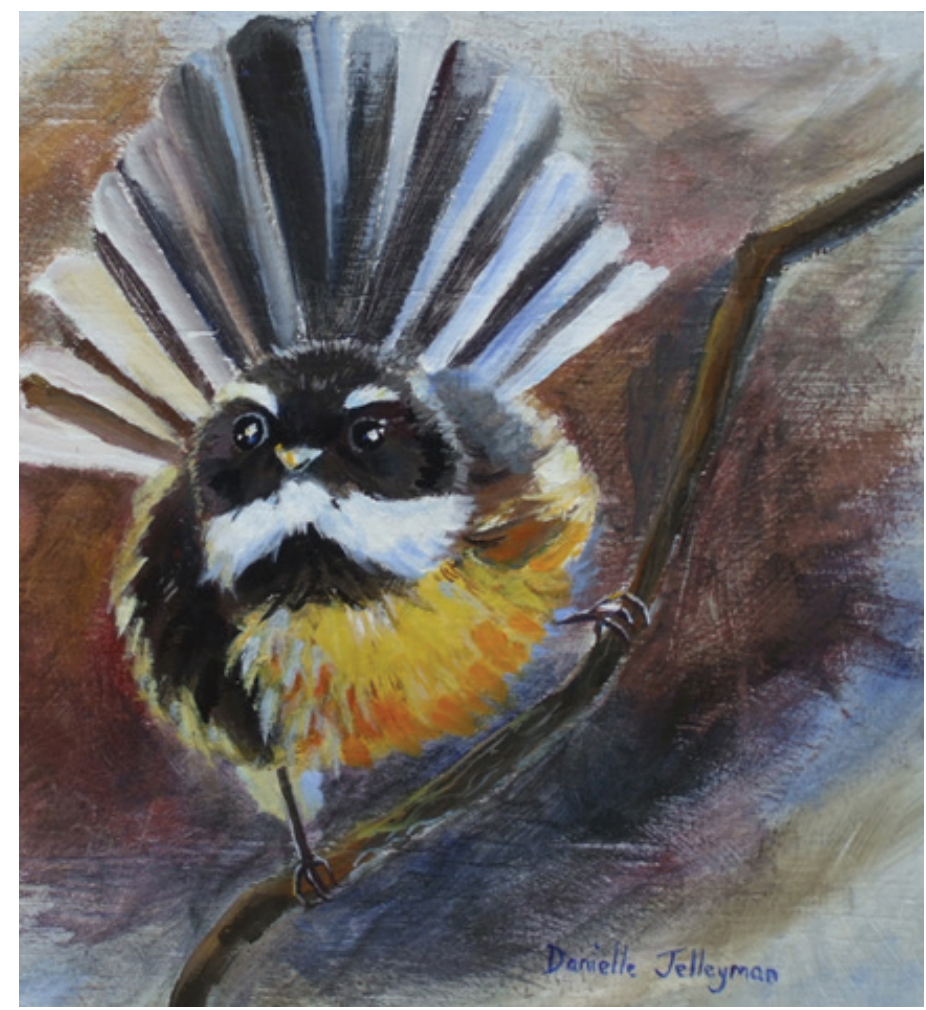

FIGURE 1 | Danielle Jelleyman, Pīwakawaka [painting].

wriggle on my stomach through a meadow - the grass is lush and thick and squeaks under my elbows. I know my friends and my brother are somewhere in the meadow too-we're making paths to see whether we'll find each other. For now, I'm happy to be on my own -I stop crawling and listen - the green grass walls around me buffer all noise, I hear a loud fly buzz past, and the dry scraping of grasshopper's legs, but the sound of a cow lowing and a tractor driving in the next field only reach me through a green haze. I nibble on some grass - it tastes juicy and bitter. I lie on my back and look at my elbow and knees - the damp grass has shared its color with me-I'm delighted to be part of the meadow.

But $\mathrm{T} \overline{1}$ is not satisfied - he hops a bit closer to me ' $\mathrm{OK}$, so this is a nice childhood memory. But why...?' Pī lands next to Tī', 'Hang on, it's my turn now. How do you teach NCAT?'. T̄ì gives Pì an annoyed peck on the head, but then settles down to listen.

On the second weekend of the programme we spend an afternoon in a park close to the College. 


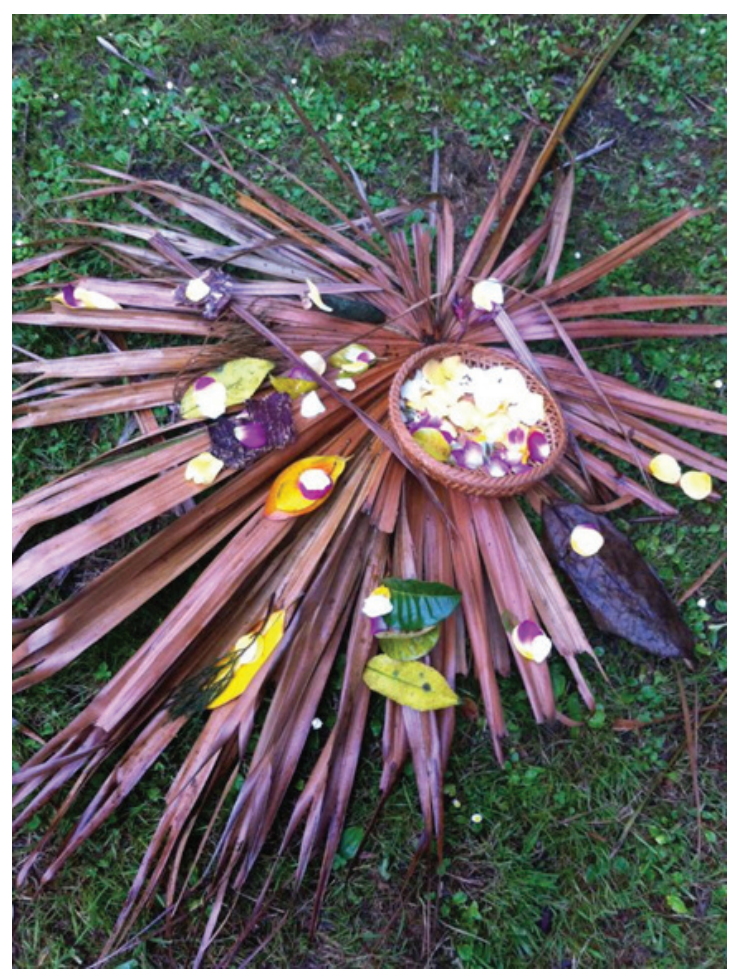

FIGURE 2 | Naomi Pears Scown, Gathering place [basket, natural materials].

When we arrive at the Botanical Garden we settle into our spot, a lawn overlooked by large, towering trees. We gather in a circle. The students are invited to find an element in nature which mirrors what they're feeling at the moment. They slowly turn around, scanning their environment. Some raise their heads to peer to the tops of the tall trees, some bend down and stroke the grass studded with daisies, some tilt their heads to listen to the bird song. One student starts, 'I feel nervous, a bit shaky inside, shivering like the leaves on that branch over there'. Our eyes lift to the small branch she points out, high up in a tree, which catches a breeze in the otherwise still day, the delicate leaves quivering. She shakes her arms and we mirror this, experiencing her anxiety and the fluttering leaves at the same time. Then the others take their turn.

I invite the students to explore the gardens surrounding the lawn. 'Your task is to find a welcoming place. How will you find this place? As humans we're used to be the active doers - we choose, we touch, we decide. Ponder the idea that nature exists independently from us, as an ensouled organism. On your 


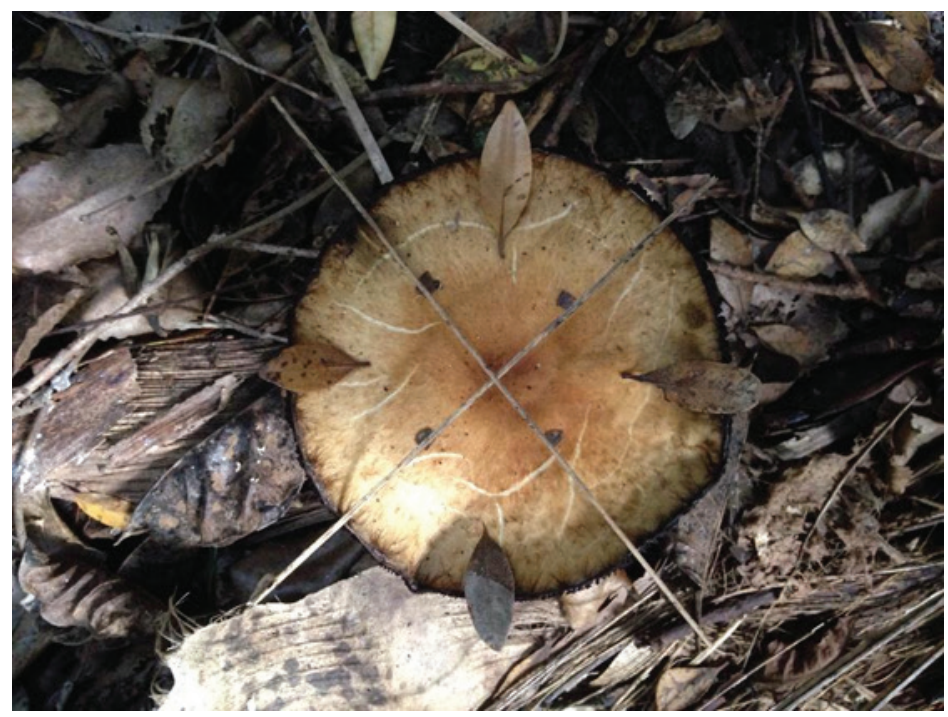

FIGURE 3 | Kirsten Pleitner, Mushroom Valley[natural materials].

wander keep your senses open and see and feel whether a tree or a place or a rock is inviting you to come and spend time with it. When this place has made itself known, introduce yourself and ask permission to sit there.

I remind the students that a journey may lead to difficult places. They're encouraged to explore this place with their senses, dialogue with it, make art from found materials, sit in silence and finally give thanks for the shelter they've received there.

After an hour we meet again and visit every place a student has spent time at. One student leads us to a prickly plant, saying she felt exposed as the plant was situated directly by the side of a path, and offered no shade on this hot day. She'd tried to ask for permission to stay at several other places but didn't feel welcome there. In the end, this place drew her back most strongly. She spent time squatting awkwardly underneath its huge, floppy leaves, observing the dull, grey and green mottled sharp dragon spikes growing along the veins of the leaves. She reached out to stroke the stem, but her hands got scratched by the rough scales covering the plant. She spent her time in conversation with the plant, realizing that this difficult place mirrored some of her own life struggles.

At the side of a sweeping lawn, below a feathered palm tree a student had arranged sticks and leaves and grass into a mandala shape. She said she'd felt so elated at being at this beautiful green oasis that she'd spun around on the grass - she demonstrated her movement and soon the whole class was spinning along with her, hair and arms flying, laughing and circling on the lawn. 


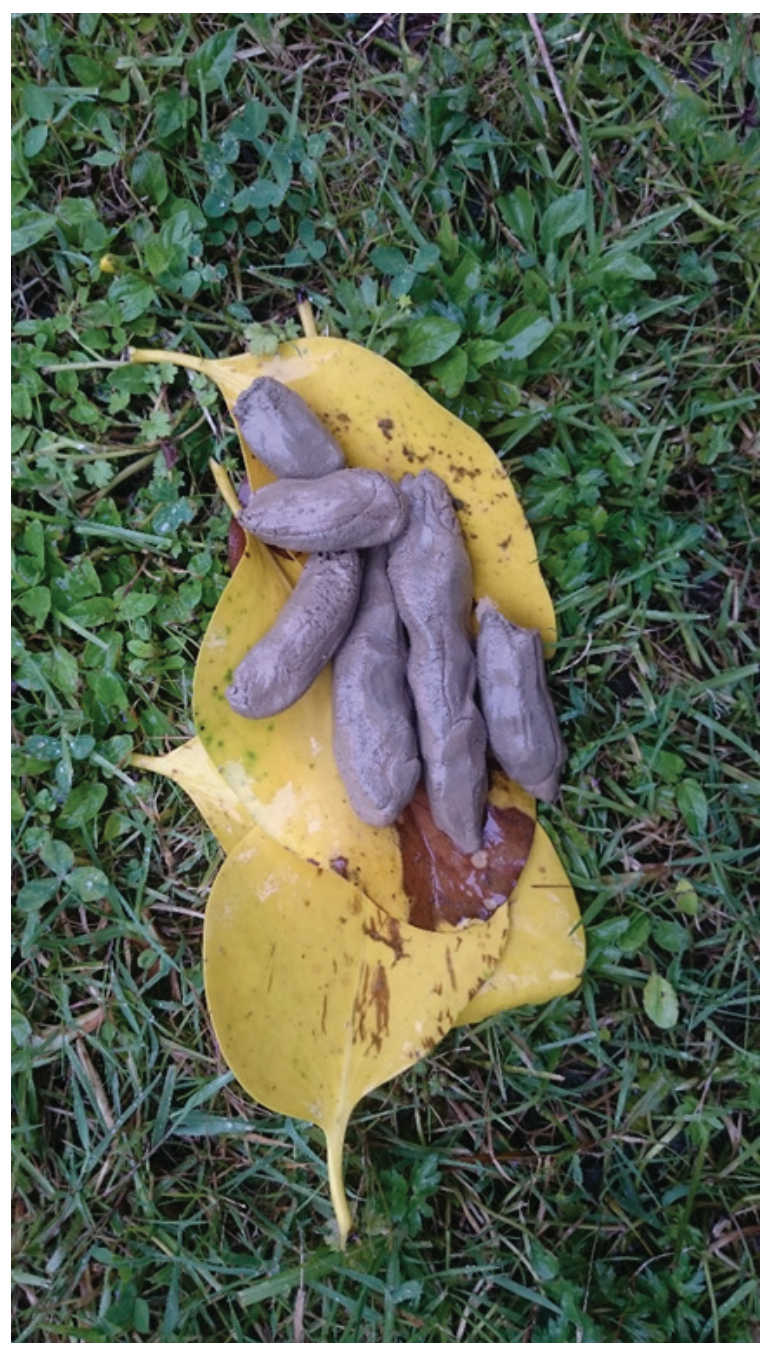

FIGURE 4 | Brett Harrington, Anger and Fear [clay, natural materials].

The next student told us she'd been disturbed by the rubbish she'd found by the side of a path, so she first gathered the rubbish and put it in a bin. Then she returned to this area and created soft wave patterns from gathered leaves and sticks to heal the place.

Another student had collected shards of broken glass and splintered sticks and arranged them with gravel on a slab of cracked concrete. She spoke about a difficult situation occurring in her life at the moment, and the need to express this.

After visiting several more places the last place we visited was hidden deep under a thicket of palm trees. The student had found a small grove where she felt at home and welcome. Soon swarms of mosquitos emerged from the 
damp hollows under the dead palm leaves and started to attack her, eventually driving her from her chosen place. She shared with us her disappointment as she'd expected this afternoon would bring a harmonious engagement with nature, and struggled with her annoyance, the interruption of her process by the mosquitos and the realization that she had to leave her place.

'It sounds very nice there,' twitters Tī. 'Yes, especially with all the mosquitos to eat!' Pī says, hopping off her branch and catching a tiny gnat in her beak. Tĩasks 'So, how does nature fit in with education and arts therapy?'.

Our two campuses in Auckland and Christchurch are inner city campuses without outdoor spaces so the opportunities to teach in nature are limited. The weekends and multi-day seminars we run are intense experiences for the students and lecturers, so it would be wonderful if we could offer more outdoor learning opportunities, as Richard Louv (2011, pp.25-30) cites a plethora of research which suggests that being in nature simultaneously calms and focuses the mind, and at the same time offers a state that transcends relaxation, allowing the mind to detect patterns it would otherwise miss'. Learning in nature also helps those students who score high on the naturalistic intelligence category, meaning they learn well through experiencing the natural world, and feel best when outdoors (Multiple Intelligences Institute, 2008)

I definitely feel a difference in my being when I've spent significant periods of time in nature, I feel grounded, whole and centered... When I've been exclusively indoors or in man-made environments, I seem to lose my center, I feel very in my head and disconnected from my body and soul. (H. Tapper, personal communication, July 29, 2018).

On the last weekend, the class... decided to take it [experiential activity] outside. The space, the air, the plethora of materials to find was tremendously freeing... It was an expansive experience, again I was very conscious of the shift from the cognitive to the feeling and sensing aspect of working outdoors with found materials... I made a mental note to utilize nature and natural materials when I am feeling stuck, uninspired, or mentally fatigued. (B. Seabridge, personal communication, July 8, 2018)

I believe that being in an unfamiliar environment is a catalyst for encouraging new thought and thus new making possibilities. I absorb the energy around me, the stale classroom makes me feel rigid and controlled. Working outdoors brings an ever-changing environment and stimulus into play. Who knows what will cross my path, what I will hear, smell, see or if I will get rained out. In dealing with these changing factors I also develop my ability to deal with and manage the changing unpredictable day-to-day task of living. (L. Durant, personal communication, May 20, 2018 


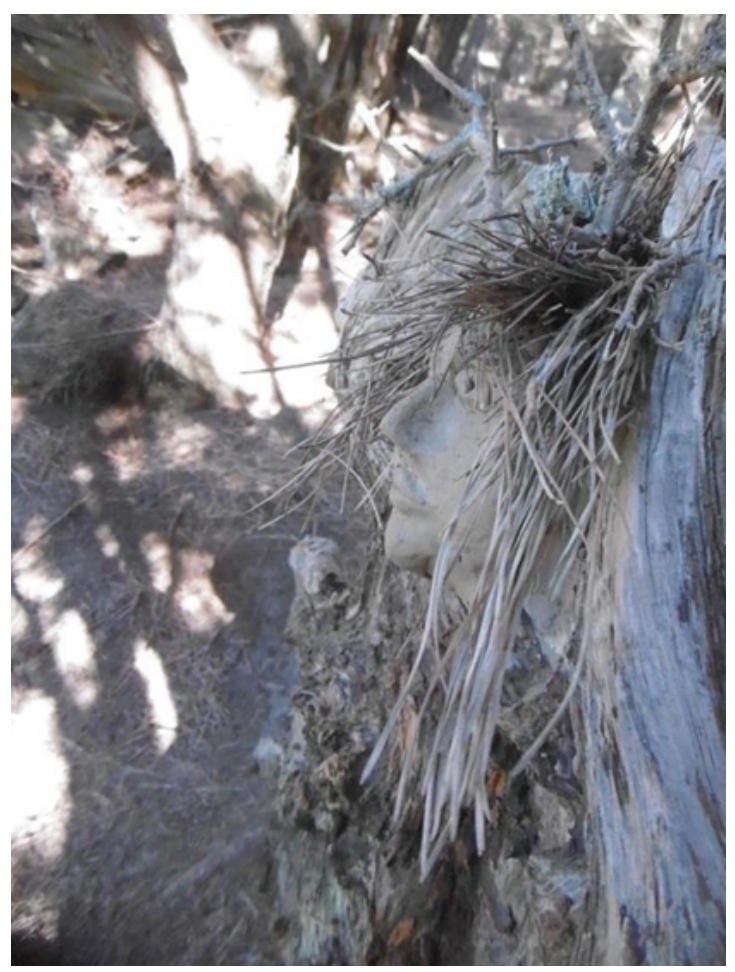

FIGURE 5 | Bettina Evans,Pine woman [clay, natural materials].

As an educator I abide by the ethics of care (Smith, 2016) for the students. This ethics of care can be extended to nature, modelling to the students a broadening of the concept of communitas, which goes beyond bonding with students from different backgrounds to engaging and co-creating with all living beings (Atkins\& Snyder., 2018). One of the main tenets in arts therapy is the creation of healthy relationships - we model this as teachers in the classroom and as therapists with our clients (Malchiodi \& Crenshaw, 2014). Nurturing a close relationship to nature encourages students to engage in communitas to create 'medicine for broken land and empty hearts' (Wall Kimmerer, 2013, p. 126).

We're part of nature, we share the same type of DNA with plants and animals and have the majority of genes in common (Hewitson, 2018), so how can nature not be included in every therapy?

I fall silent. Tī and P1i look at me and tweet encouragingly. I take a deep breath.

In the classroom, the students engage with the lecturer, the art materials and the space. As soon as we step into nature, the natural space becomes the therapist. Being surrounded by nature can be stress-reducing, engendered by the sensory immersion, which engages us in staying in the present moment 
(Robinson, 2013). As an arts therapist/teacher I work as a co-facilitator with nature, extending invitations to students to connect through art making and movement in response to what is observed to deepen the experience.

When I asked the tree what I might give it in return, I had the sense that I was to
witness the tree, to see its true beauty. I took a number of close-up images of the
tree and was amazed at the variety of textures, nooks and crannies. There were
areas of aesthetic beauty and areas where the wood was rotting, where spider
webs and lichen were in residence and where, in the smallest spaces between
branches, new growth could be found- a tiny plant growing from a handful of
dirt. A large root was exposed, winding powerfully down into the earth.
Witnessing the tree in this way, I was able to connect with the conditions that
both the tree and I shared - age, decay, strength, stability, groundedness,
brokenness, new growth. I reflected on the fact that the same tree had initially
(at the beginning of the session) reflected my own disconnection and yet, by the
end of this session, reflected complete peace, grounding and connection. (S.
Knaap, personal communication, August, 28, 2018)

Training to be an arts therapist is hard work, and it's easy to become overwhelmed. We need all the help we can get and NCAT can provide a means of self-care for students and teachers.

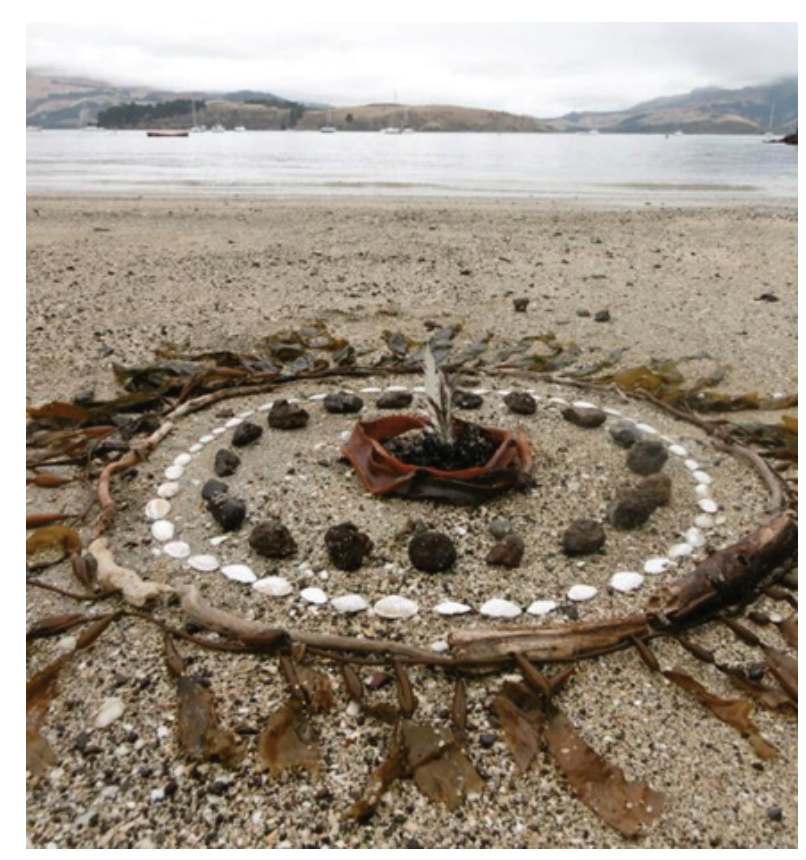

FIGURE 6 | Bettina Evans, Self-care mandala [natural materials]. 
To bring aspects of nature into the classroom we offer a variety of natural materials such as stones, sticks, shells, leaves, seeds etc.

I found it easier to connect with the natural art materials provided as they already hold such a strong reference to the world. I am often worried about the effect our art materials have on our environment and how wasteful they might be, so I also enjoyed that we were repurposing some found natural materials and ... they could be returned to nature again. (L. Durant, personal communication, May 20, 2018)

I will often opt using natural resources when I create, even in a classroom setting when other materials are offered. I love the feeling of natural resources, how I feel connected to my earth mother and to my ancestors. I do not like feeling I am doing harm with what I create. I struggle to use glitter or plastic, colored, packaged, manufactured materials... I always prefer natural colors. I paint in clay and use oxides and soil. I guess this comes back to ahimsa, to do no harm. (H. Garisau, May 22, 2018 personal communication)

After three years of teaching NCAT it is starting to bear fruit: One of our students, Naomi Pears-Scown, used her Master's thesis to research and provide alternatives to the mostly man-made art materials used by arts therapists. Thesis includes a curated guide of environmentally sensitive art materials, to share her knowledge with others in the field.

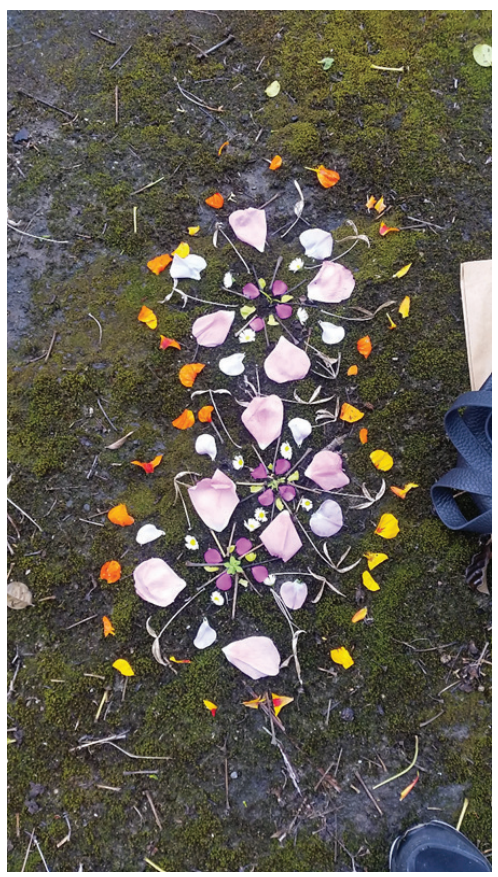

FIGURE 7 | CarrieWeston,Petal arrangement [natural materials]. 
NCAT fits well with Māori values of mauri (treating every living thing with respect), wairua (connection to whenua [land]) and kaitiakitanga (guarding of natural resources, reciprocity)(Hauora, 2016). The NCAT teaching is followed by indigenous knowledge system teachings, introducing Māori creation stories. My hope is that teaching NCAT with all its facets will provide the students with another helpful tool on their journey to become an arts therapist.

I look at T̄̄ and $\mathrm{P} \overline{1}$. 'Much luck!' they twitter, and they plunge from their branch, flick their tails and disappear into the depth of angaio bush.

I stretch and get up. My head is feeling clearer. The sun has sunk behind the hill, but the water in the harbor still shimmers pink and silver. Time to retrace my steps along the muddy winter path, time to go home.

\section{About the Author}

Bettina works as a lecturer and course-coordinator for Whitecliffe College in a part-time capacity. She also works in private practice from a studio in Lyttelton and runs arts therapy workshops for a variety of health/mental health organisations. She came to arts therapy after working as an educator, teacher, community facilitator and community event organiser for NGOs in Canterbury. She trained and worked as a gardener for many years, often in community settings. Her experience of the healing effect of nature on herself and others has influenced her practice as an arts therapist.

\section{References}

Atkins, S. \& Snyder, M. (2018). Nature based Expressive Arts Therapy. Philadelphia, PA: Jessica Kingsley Publisher.

Hauora. K. (2016). Tikanga Maori Values. Rangataki Tu Rangatira. Retrieved from https://www.r2r.org.nz

Hewitson, J. (2018). Genetics, DNA, Plants and Humans. Science and Plants for Schools. Retrieved from http://www.saps.org.uk/saps-associates/browse-q-and-a/473-how-much-dna-do-plants-share-with-humansover-99

Louv, R. (2010). The Last Child in the Woods. 2nd ed. New York, NY: Workman Publishing.

Malchiodi, C. \& Crenshaw, D. (2014). Creative Arts and Play Therapy for Attachment Problems. New York: NY: Guildford Press.

Multiple Intelligence Institute (2008). MI Basics: The Theory. Retrieved from: http://www.multipleintelligences.org/uploads/download/MI_Basics.pdf

Robinson, I. (2013). Psychotherapy as if the world mattered. In L. Buzzel \& C. Chalquist (Eds.), Ecopsychology. (pp.24-29). San Francisco, CA: Sierra Book Club.

Smith, M. K. (2016). Nel Noddings, the Ethics of Care and Education. The Encyclopaedia of Informal Education. Retrieved from http://infed.org/mobi/nel-noddings-the-ethics-of-care-and-education/. Wall Kimmerer, R. (2013) Braiding Sweetgrass. Minneapolis, MI:Milkwood. 